\title{
在宅患者の爪白癬外用療法における薬局薬剤師の役割
}

\author{
山浦克典, ${ }^{*, a}$ 林 直子, ${ }^{a}$ 今津嘉宏, ${ }^{b, c}$ 米田吉位, ${ }^{d}$ 内田恵美子, ${ }^{e}$ 鈴木順子 $c$
}

\section{Role of Pharmacists in Topical Therapy for Onychomycosis in the Home-care Setting}

\author{
Katsunori Yamaura, ${ }^{*, a}$ Naoko Hayashi, ${ }^{a}$ Yoshihiro Imazu, ${ }^{b, c}$ Yoshitaka Yoneta, ${ }^{d}$ \\ Emiko Uchida, ${ }^{e}$ and Junko Suzuki ${ }^{c}$ \\ ${ }^{a}$ Faculty of Pharmacy, Keio University; 1-5-30 Shibakoen, Minato-ku, Tokyo 105-8512, Japan: ${ }^{b}$ Shibadaimon \\ Imazu Clinic; 1-1-14 Shibadaimon, Minato-ku, Tokyo 105-0012, Japan: 'Kitasato University School of \\ Pharmacy; 5-9-1 Shirogane, Minato-ku, Tokyo 108-8641, Japan: ${ }^{d} Y^{\prime}$ s Clinic; 4-13-7 5F Minamiazabu, \\ Minato-ku, Tokyo 106-0047, Japan: and ${ }^{~ N u r s e ~ S t a t i o n ~ T o k y o ; ~ 3-15-7-102 ~}$ \\ Roppongi, Minato-ku, Tokyo 106-0032, Japan.
}

(Received May 17, 2017)

\begin{abstract}
There is an urgent need to promote home medical care in Japan because of the country's superaging society. Community pharmacists are expected to play an important role as part of home medical care teams. The prevalence of nail ringworm is high among home-care patients and can cause decreases in the quality of life, including difficulty in walking due to pain caused by nail deformation and inflammation around infected nails. Nail ringworm is typically treated with oral medication. However, the condition is left untreated in many elderly patients because of the risk of drug-drug interactions or concerns about severe liver damage. Efinaconazole, a novel triazole antifungal agent, has recently become available in Japan, enabling patients with nail ringworm to be treated with a topical medication. In topical treatment, the method of application is important because of its major impact on the therapeutic effect. Therefore, pharmacists should take special care to instruct patients and caregivers on the proper use of topical efinaconazole. Adherence to oral medication can be easily monitored by checking the number of tablets or capsules remaining, but adherence to topical medication regimens is more difficult to assess because the remaining amount cannot be determined precisely by checking the outer appearance of the container. The aim of this study was to determine and improve home-care patients' adherence to topical efinaconazole treatment regimens by measuring amounts remaining in the containers using a portable electronic scale. We found that this method is useful for determining the status of topical efinaconazole use.
\end{abstract}

Key words - onychomycosis; efinaconazole; dermatology

\section{はじめに}

超高齢社会に突入したわが国では，在宅医療の充 実が喫緊の課題となっている。地域薬局において は, 薬局薬剤師が在宅医療チームの一員として参画 し，専門性を発揮することが期待されている．在宅 患者において, 爪白癬は罹患率が高く, 進行すると 爪の変形，爪周囲の皮膚炎に伴う痛みにより，歩行

a慶應義塾大学薬学部（干105-8512 東京都港区芝公園 1-5-30), b芝大門いまづクリニック（テ105-0012 東京 都港区芝大門 1-1-14), ${ }^{c}$ 北里大学薬学部（干108-8641 東京都港区白金 5-9-1），dワイズクリニック（†1060047 東京都港区南麻布 4-13-7 5F), eナースステー ション東京(干106-0032 東京都港区六本木 3-15-7-102)

*e-mail: yamaura-kt@keio.jp

本総説は, 日本薬学会第 136 年会シンポジウムS55 で

発表した内容を中心に記述したものである.
困難を来すなど，患者及び介護家族の QOL の低下 をもたらす。一方，爪白癬治療は通常内服薬による 薬物療法となるが, 高齢の在宅患者においては肝障 害の誘発や多剂併用に伴う薬物間相互作用の懸念に より，未治療及び治療放置者が多いのが現状であ る. 近年, 新規トリアゾール系化合物エフィナコナ ゾールの外用爪白癬治療剂が発売され，外用薬のみ で爪白癬の治療が可能となつた。 1,2$)$ これにより，未 治療及び治療放置されてきた爪白癬に罹患した在宅 患者の治療の進展が期待される. 外用薬は, 塗布の 手技が治療効果に著しく影響するため, 治療におけ る薬剤師の服薬指導の役割は大きい. 3,4$)$ 在宅患者の 内服薬の服薬状況は, 残薬を確認することでかなり 正確に把握できる。 一方, 外用薬の場合, チューブ 入り軟膏剤や点眼剂ならば目視で大まかな使用状況 
を確認できるものの, 変形しない遮光容器に封入さ れた薬剤の残薬確認は目視では不可能である. そこ でわれわれは，エフィナコナゾール外用薬のアドヒ アランスの把握と向上を目的に，残薬確認を携帯型 電子天科による重量管理で試みた. 複数本のエフィ ナコナゾール外用薬が平行使用される症例では, 全 容器にナンバリングを施し, 合計重量変化により使 用状況が把握可能であった。 罹患爪数と使用日数か ら標準使用量を算出し, 使用量が不十分な場合は, 薬剂師が塗布方法を指導するなどの介入により，爪 白癬の治療効果向上に貢献可能と思われる.

\section{在宅患者における爪白癬治療の課題}

爪白癬治療は，通常内服治療で行われている。し かし，在宅医療を受ける患者の多くが高齢者であ り，様々な疾患を併発している。このため，多剤併 用による薬物療法が行われ, 重複投薬相互作用のリ スクを負っている. 通院治療が可能な患者と比較 し，運動機能のみならず肝機能及び腎機能の低下を 認めることが多く，体内薬物動態の変動や全身状態 を評価した上での薬物治療が求められる.

爪白癬治療に用いられる治療薬は, テルビナフィ ン錠，イトラコナゾールカプセルの内服， $10 \%$ エ フィナコナゾール爪外用液が用いられる。内服薬と して用いられるテルビナフィン錠の副作用として, 重篤な肝障害 (肝不全, 肝炎, 胆汁うつ滞, 黄疸等) 及び汎血球減少, 無顆粒球症, 血小板減少があらわ れることがあり，死亡に至った例も報告されてい る.また，禁忌として，（1）重篤な肝障害のある患 者（肝障害が増悪するおそれがある），（2）汎血球 減少, 無顆粒球症, 血小板減少等の血液障害のある 患者（血液障害が増悪するおそれがある），(3）本 剤の成分に対し過敏症の既往歴のある患者, とされ ている. イトラコナゾールカプセルは慎重投与とし て，1）薬物過敏症の既往歴，アレルギー既往歴のあ る患者，2）肝障害のある患者（肝障害を悪化させる おそれがある），3）腎障害のある患者（本剂及び代 謝物等の排泄が遅延し, 副作用があらわれ易くなる おそれがある)，4）うつ血性心不全又はその既往歴 のある患者（うつ血性心不全の悪化又は再発を来す おそれがある)，5）高齢者，とされており，どちら の薬剂も，在宅医療を受ける患者に対して投与する 場合，基礎疾患の厳密な評価に加え，定期的な血液 検査による副作用モニタリングを前提とした治療選
択が必要となる。

爪白癬治療の外用薬についても, 内服治療薬同 様, 血中濃度上昇に伴う副作用を考慮する必要があ る。健常人であれば，問題とならない血中濃度で も，在宅患者においては，肝機能及び腎機能が低下 している症例が多く，その影響は無視することがで きない. 10\%エフィナコナゾール爪外用液の爪中濃 度及び血漿中濃度を爪白癬治療内服薬と比較する と，テルビナフィン錠では，爪甲中濃度は 12 週で $0.78 \mu \mathrm{g} / \mathrm{g}$, 血漿中濃度は, 単回 $\mathrm{C}_{\max }=725 \mathrm{ng} /$ $\mathrm{mL}$ ，イトラコナゾールカプセルでは，爪甲中濃度 は 24 週で $0.4 \mu \mathrm{g} / \mathrm{g}$, 血漿中濃度は, 7 日後 $\mathrm{C}_{\max }=$ $1000 \mathrm{ng} / \mathrm{mL}$ となる。これと比較し，10\%エフィナ コナゾール爪外用液は，爪甲中濃度は 4 週で 6000 $\mu \mathrm{g} / \mathrm{g}$, 血漿中濃度は, 4 週で $1.3 \pm 1.2 \mathrm{ng} / \mathrm{mL}$ とな る. 1)

爪白癬治療の外用薬である $10 \%$ エフナコナ ゾール爪外用液は, 爪白癬治療の内服薬と比較し, 有効爪甲中濃度に対する血漿中濃度比が極めて小さ い特徵を有するため, 肝機能及び腎機能低下症例の 多い在宅医療において, 安全に安心して使用するこ とが可能と考えられる。安全性の面から在宅医療に おける爪白癬治療の第一選択薬は, 内服薬ではな く，外用薬であるべきことが明白である.

\section{エフィナコナゾールの安全性とコスト}

新規トリアゾール系エフィナコナゾールは, わが 国初の外用爪白癬治療薬である。特徵は, ケラチン との親和性が低く，爪甲での透過性に優れており， 爪甲内及び爪床で高い抗真菌活性を発揮する点であ る. また，基剤対照二重盲検比較試験として実施し た第III相試験（国際共同及び海外試験）において, 本剂の爪白癬に対する優れた臨床効果が確認されて いる．第吕相試験（国際共同及び海外試験）におけ る安全性評価対象例 1227 例（日本人患者 184 例を 含む）中，副作用（臨床検查值異常を含む）の発現

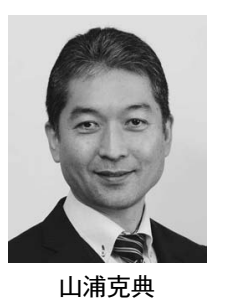

慶應義塾大学薬学部医療薬学・社会連 携センター副センター長, 社会薬学部 門 教授, 附属薬局長. 千葉大学薬学部 及び同大学大学院博士前期課程修了 後, 株式会社ツムラ薬理研究員, 東 京・埼玉・茨城で保険薬局薬剂師, 株 式会社富士バイオメディックス臨床開 発モニ夕一, 千葉大学大学院薬学研究 院講師, 同准教授を経て現職. 
症例は 78 例 $(6.4 \%)$ であつた。その主なものは, 適用部位にみられ，皮膚炎 26 例 $(2.1 \%)$, 水疮 18 例 $(1.5 \%)$, 紅斑 9 例 $(0.7 \%)$, そう痒, 異常感覚, 腫脹，疼痛，皮膚剥脱各 7 例 $(0.6 \%)$, 爪甲脱落 4 例 $(0.3 \%)$ 等であった。なお，日本人患者（184 例）での副作用発現症例は 17 例（9.2\%）であり， その大部分は適用部位の皮膚炎 15 例 $(8.2 \%)$ で あった．このことからも，在宅患者の爪白癬治療に おいて，医師，薬剤師，看護師などが安心して，安 全に使用することができる薬剤と考えられる.

テルビナフィン錠，イトラコナゾールカプセル， $10 \%$ エフィナコナゾール爪外用液による爪白癬治療 にかかるコストについて比較した。 28 日分の治療 コストを薬価べース（2015 年度薬価）で算出する と，テルビナフィン錠は 200 円 $\times 28$ 日 $=5,600$ 円， 一方イトラコナゾールカプセルは 1 週間服用後 3 週 間休薬するパルス療法のため 3,160 円 $\times 7$ 日 $=$ 22,210 円となる。また，10\%エフィナコナゾール 爪外用液は爪 3 枚に対する標準使用量である 1 ボ卜 ル 28 日分で計算すると， 1657.5 円 $\times 3.56 \mathrm{~g}=5,900$ 円となり，28 日分の比較では，テルビナフィン錠 が最も安価となり，イトラコナゾールカプセルが高 価となる，各々の臨床成績は，テルビナフィン錠 24 週間投与の有効率 $84.4 \%$ ，イトラコナゾールカ プセルのパルス療法 12 週間投与の有効率 84.6\%, $10 \%$ エフィナコナゾール爪外用液 48 週間投与の完 全治癒率 $28.8 \%^{5)}$ となる。 上記臨床成績より治療期 間を加味した場合の治療コストは，テルビナフィン 錠 24 週間内服で 33,600 円，イトラコナゾールカプ セル 12 週間内服で 66,400 円，10\%エフィナコナ ゾール爪外用液 48 週塗布で 70,800 円となる．以上 より，有効率を考慮した治療コストでは，テルビナ フィン錠が最も安価であり，10\%エフィナコナゾー ル爪外用液が高価と考えられた。なお，上記試算は 先発医薬品により算出しており，後発医薬品を用い た場合，コストは変わるが順位に変動はない。一 方，各薬剤の臨床試験成績は評価指標が異なる点に 注意しなければならない。例えば，テルビナフィン 錠やイトラコナゾールカプセルは罹患爪の混濁比の 改善を指標としているのに対し，エフィナコナゾー ル爪外用液は完全治癒率，つまり全く新しい爪に置 き換わるという厳しい評価指標を採用しているた め, ひとくくりに比較はできない。ささら，実臨床

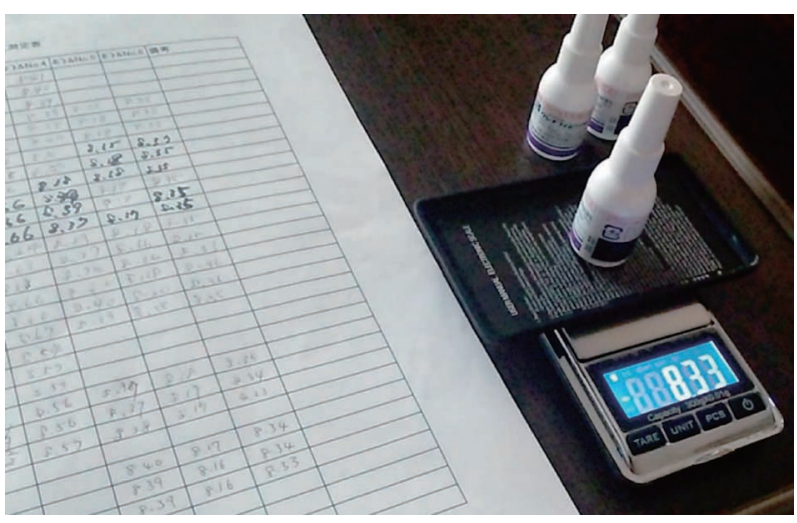

Fig. 1. Weighing the Remaining Amount of Topical Efinaconazole Using a Portable Electronic Scale

においては患部の病型や病巣環境等の影響で治癒期 間が前後することも考慮しなければならない.

\section{爪白癬外用治療における薬局薬剤師の役割}

在宅医療における薬剤師の役割は，在宅患者に対 する最適かつ効率的で安全・安心な薬物療法の提供 を行うために，処方せんに基づき患者の状態に応じ た調剤（一包化，懸濁法，麻薬，無菌調剂），患者 宅への医薬品・衛生材料の供給，薬歴管理（薬の飲 み合わせの確認)，服薬の説明（服薬方法や効果等 の説明，服薬指導・支援)，服薬状況と保管状況の 確認（服薬方法の改善，服薬カレンダー等による服 薬管理)，副作用等のモニタリング，在宅担当医へ の処方支援（剂形・服用時期等を含む患者に最適な 処方の提案), 残薬管理, 麻薬の服薬管理と廃薬, ケアマネジャー等の医療福祉関係者との連携・情報 共有，医療福祉関係者への薬剤に関する教育, $\left.{ }^{6}\right)$ が 求められる.

しかし, 外用薬のアドヒアランスは, 内服薬と比 較して評価が難しい. $\left.{ }^{3}\right)$ 外用薬は，使用開始後から アドヒアランスが低下し，使用率は 1 週目で 84.6 \%であったものが，4 週後には $66.8 \% ， 8$ 週後には, $51 \%$ まで低下すると言われている. ${ }^{4)}$

在宅医療における爪白䲗治療では，安全に安心し て使用することができる外用薬が第一選択薬となる が，アドヒアランスが内服薬よりも悪ければ，治療 効果を期待することができない，特に患者本人が認 知症などの高次機能障害を有する場合や老老介護な ど，家族の協力が得られない場合を考えると，さら にアドヒアランスが低下する可能性がある.

今回，われわれは，10\%エフィナコナゾール爪外 
Table 1. Gravimetric Record for the Management of Adherence to Topical Efinaconazole

Patient: $* * * * * *$

\begin{tabular}{c|c|c|c|c|c|c|c}
\hline \hline \multicolumn{1}{c|}{ Date } & Bottle 1 & Bottle 2 & Bottle 3 & Bottle 4 & Bottle 5 & Bottle 6 & Amount used (g) \\
\hline 6 Oct 2015 & & & & & & & \\
\hline 13 Oct 2015 & 0.03 & 0.03 & 0.01 & 0.01 & - & - & 0.08 \\
\hline 20 Oct 2015 & 0.11 & -0.05 & -0.01 & 0.00 & 0.00 & -0.01 & 0.05 \\
\hline 2 Oct 2015 & 0.06 & 0.13 & -0.01 & 0.00 & -0.01 & 0.01 & 0.18 \\
\hline 2 Nov 2015 & 0.05 & -0.02 & 0.03 & 0.01 & 0.01 & 0.01 & 0.09 \\
\hline 10 Nov 2015 & 0.02 & 0.20 & -0.03 & -0.02 & -0.02 & -0.01 & 0.14 \\
\hline 17 Nov 2015 & - & 0.33 & 0.01 & 0.02 & 0.01 & 0.02 & 0.38 \\
\hline 24 Nov 2015 & - & 0.24 & 0.00 & -0.02 & 0.02 & 0.00 & 0.24 \\
\hline 1 Dec 2015 & - & 0.21 & 0.04 & 0.01 & -0.02 & -0.01 & 0.23 \\
\hline 7 Dec 2015 & - & 0.26 & 0.00 & 0.03 & 0.02 & 0.00 & 0.32 \\
\hline
\end{tabular}

用液であるクレナフィンを用いて，外用薬のアド ヒアランスを検討した。 内服薬は，残薬をカウント すれば服薬状況を簡単に把握することができるが, 遮光ボトルであるクレナフィンは，内容量が目視 では確認できない。また， 1 回使用量も， $100 \mu \mathrm{L}$ と 微量なため，透明ボトルだとしても目視での管理が 困難である，さらに，在宅患者では多職種が外用療 法に係わることがあり，病院や介護施設へ持参する こともあることから，複数のボトルを並行して使用 している場合が多い，そこで，まず在宅患者宅へ訪 問し，処方されたすべてのクレナフィンホホトルを 確認し，それぞれのボトルに番号をナンバリング し，アドヒアランスを確認する目的でボトル重量の 初期値を携帯型電子天秤で測定した（Fig. 1)。そ の後, 定期的に在宅患者宅を訪問し, すべてのナン バリングされたボトル重量を測定し使用量を解析し たところ，実際に使用された外用薬量と理論上の使 用量に大きな差を認めた。すなわち，罹患爪に対し て爪白癬治療を行った場合, クレナフィンでは, 1 週間に 0.3-0.42 g 必要とするが，実際に使用された 薬液量を, 重量測定結果から算出すると, 介入前の 11 月 10 日までは 0.05-0.18 g に留まっていた（Table 1).

10\%エフィナコナゾール爪外用液のボトル重量測 定管理のメリットは，使用量を数值化でき，使用不 足と過剰使用の判断が可能で，在宅医療における薬 剤師の介入の明確な判断材料となることである。ま た，正確な残薬量の把握が可能となり，不要な処方
を回避することができるので，医療費の削減につな がる。 クレナフィンは開封後 4 週間経過した残液 は使用できないので，複数の外用ボトルを同時に使 用する症例においては，開封後の使用期限の管理に も有用である.

\section{おわりに}

2014 年 6 月, 改正薬剂師法が施行され, 薬剤師 法 25 条の 2 において，これまで情報提供までだつ た薬剤師の責任は，薬学的知見に基づく指導が加 わつたことから，薬物治療開始後の有効性，安全性 についても責任を負わねばならない. 7) 今回，爪白 癬治療において $10 \%$ エフィナコナゾール爪外用液 のボトル重量管理による服薬アドヒアランスの評価 を通して，在宅患者のアドヒアランス向上における 薬剤師の役割を示すことができた.

\section{利益相反＼cjkstart開示すべき利益相反はない.}

\section{REFERENCES}

1) Sakamoto M., Sugimoto N., Kawabata H., Yamakawa E., Kodera N., Pillai R., Tatsumi Y., J. Drugs Dermatol., 13, 1388-1392 (2014).

2) Sugiura K., Sugimoto N., Hosaka S., Katafuchi-Nagashima M., Arakawa Y., Tatsumi Y., Jo Siu W., Pillai R., Antimicrob. Agents Chemother., 58, 3837-3842 (2014).

3) Zaghloul S. S., Goodfield M. J., Arch. Dermatol., 140, 408-414 (2004). 
4) Carroll C. L., Feldman S. R., Camacho F. T., Manuel J. C., Balkrishnan R., J. Am. Acad. Dermatol., 51, 212-216 (2004).

5) Watanabe S., Igarashi A., Katoh T., Matsuda T., Yamada K., Nishimoto K., Nishi Nihon Hifuka, 77, 256-264 (2015).

6) Ministry of Heath, Labour and Welfare: 〈http://www.mhlw.go.jp/stf/shingi/2r98520 00000zap2-att/2r9852000000zatv.pdf $\rangle$, cited
11 September, 2016.

7) Ministry of Health, Labour and Welfare: 〈http: // wwwhourei.mhlw.go.jp / cgi-bin / t docframe2.cgi?MODE = hourei\&DMODE = SEARCH\&SMODE $=$ NORMAL \&KEYWORD $=\% 96 \% \mathrm{f} 2 \% 8 \mathrm{~d} \% \mathrm{dc} \% 8 \mathrm{e} \% 74 \% 96 \% 40 \% 81 \%$ $40 \% 8 \mathrm{e} \% 77 \% 93 \% \mathrm{~b} 1 \& \mathrm{EFSNO}=758 \& \mathrm{FILE}=$ FIRST\&POS $=0 \& H I T S U=19\rangle, \quad$ cited 23 March, 2018. 